\title{
Physiological and Biochemical Effects of an Aqueous Extract of Lemna minor L. as a Potential Biostimulant for Maize
}

\author{
Daniele Del Buono $^{1}$ (D - Maria Luce Bartucca ${ }^{1} \cdot$ Eleonora Ballerini $^{2} \cdot$ Biancamaria Senizza $^{3} \cdot$ Luigi Lucini $^{3}[$. \\ Marco Trevisan ${ }^{3}$ (1)
}

Received: 23 February 2021 / Accepted: 7 September 2021 / Published online: 14 September 2021

(C) The Author(s) 2021

\begin{abstract}
Biostimulants are receiving increasing attention for their beneficial effects on crops, driving interest in identifying new plant extracts that could exert such stimulatory effects. This work aimed to evaluate the potential of an aqueous extract obtained from duckweed (Lemna minor L.), a freshwater species, to act as a biostimulant in maize. For this purpose, duckweed plants were collected from a natural basin and then transferred, stabilized, and grown under controlled conditions. The duckweed extract was first characterized through untargeted profiling, which revealed an abundance of bioactive phytochemicals. A relatively high amount of low-molecular-weight secondary metabolites such as phenolics $\left(6714.99 \mathrm{mg} \mathrm{kg}^{-1}\right)$ and glucosinolates $\left(4563.74 \mathrm{mg} \mathrm{kg}^{-1}\right)$ were present in the plant extract. Maize seeds were primed with different concentrations of this extract $(0.01 \%, 0.05 \%, 0.50 \%$, and $1.00 \%$, dry weight/water volume), and some physiological and biochemical traits of the crop were recorded. The duckweed extract improved maize germination, biomass, leaf area, pigment content, and vigor index. The most effective treatment was the $0.50 \%$ concentration, which improved the majority of the measured growth traits. The extract at concentrations of $0.05 \%, 0.50 \%$, and $1.00 \%$ stimulated the assimilation of nitrogen $(\mathrm{N})$, phosphorous $(\mathrm{P})$, potassium $(\mathrm{K})$, calcium $(\mathrm{Ca})$, magnesium $(\mathrm{Mg})$, sodium $(\mathrm{Na})$, iron $(\mathrm{Fe})$, and copper $(\mathrm{Cu})$. In summary, this study revealed that duckweed is a promising species that can be cultured and grown under controlled conditions for obtaining extracts with biostimulant properties.
\end{abstract}

Keywords Phytochemicals $\cdot$ Phenolic compounds $\cdot$ Glucosinolates $\cdot$ Plant biostimulant $\cdot$ Biomass production $\cdot$ Nutrient acquisition

\section{Introduction}

As the global demand for food increases, cropping systems will have to respond with ever-greater production (Mancosu et al. 2015). At the same time, the high impact of agriculture

Handling Editor: Wendy stirk .

Luigi Lucini

luigi.lucini@unicatt.it

1 Dipartimento Di Scienze Agrarie, Alimentari Ed Ambientali, Università Di Perugia, Borgo XX Giugno 74, 06121 Perugia, Italy

2 Dipartimento Di Chimica, Biologia E Biotecnologie, Università Degli Studi Perugia, via Elce di Sotto 8, 06123 Perugia, Italy

3 Department for Sustainable Food Process, Università Cattolica del Sacro Cuore, via Emilia Parmense 84, 29122 Piacenza, Italy on the environment means that future solutions will need to be more sustainable and eco-friendly (Sarkar et al. 2020). Cropping systems will also need to be more resilient to climate change, which will place intense pressure on agriculture in the coming decades (Blattner 2020).

The objective of increasing crop production has led to the application of new substances called plant biostimulants, which can substantially improve plant growth and performance (Del Buono 2021). A biostimulant can be defined as any substance or microorganism that, when applied to a crop, can enhance its nutrition, quality, and resistance to abiotic stress, regardless of its nutrient content (du Jardin 2015). Plant biostimulants do not fall under the pesticide regulatory framework because they do not directly affect pests (du Jardin et al. 2020; Van Oosten et al. 2017). Different materials have been grouped together under the label of plant biostimulants; these include seaweed extracts, plant extract and hydrolysate, beneficial microorganisms, humic 
and fulvic substances, and animal protein hydrolysate (Rouphael and Colla 2020). Commercial products containing mixtures of these substances and/or microorganisms are also considered biostimulants (du Jardin 2015).

Plant biostimulants attract attention for their effectiveness in stimulating some morphological, physiological, and biochemical processes in crops (Del Buono et al., 2021). Biostimulants can enhance the ability of plants to use and assimilate nutrients, improve their growth, and positively affect the quality of the end product (Rouphael and Colla 2020). Biostimulants can also increase plant resistance to abiotic stresses of various types, the ability to cope with detrimental conditions, and maintain productivity (Panfili et al. $2019 b$ ). In addition, the use of biostimulants can also lead to significant reductions in agrochemical inputs, limiting the environmental pressure of the farming systems (Puglia et al 2021).

Despite the popularity and widespread use of biostimulants, there is still ongoing research to find new stimulatory substances from a broad array of raw materials, and particular interest is being paid to plant extracts (Abd El-Mageed et al. 2017; Zulfiqar et al. 2019). The appeal of plant extracts is due to their biocompatibility and a general drive toward integrating agriculture into a green and circular economy (Sherwood 2020).

The ability of extracts obtained from certain algae to stimulate crop growth and improve stress resistance is well documented (Gebreluel et al. 2020). On the contrary, little or no attention has been paid to freshwater aquatic species such as Lemna minor L. (duckweed) that is already used in ecological and phytoremediation studies (Khan et al. 2020; Panfili et al. 2019a, 2019b). Duckweed is a free-floating species in the family of Lemnaceae native to several continents, widely distributed in wetlands, lagoons, and ponds, and with a rapid growth rate. In wastewater, the species can produce up to $12.4 \mathrm{~g} \mathrm{~m}^{-2}$ day $^{-1}$ dry weight (Liu et al. 2019). This plant can survive in very adverse conditions, with temperatures ranging between 5 and $35{ }^{\circ} \mathrm{C}$, and $\mathrm{pH}$ between 3.5 and 10.5 (Khellaf and Zerdaoui 2010; Lasfar et al. 2007). In addition, duckweed is effective in removing organic and inorganic toxic substances from water and has the capacity to remediate water polluted by toxic metals (Khan et al. 2020). Due to its antioxidant activities, inducible by bioactive compounds, duckweed can be used to remediate water polluted by herbicides (Panfili et al. 2019a).

Duckweed has been the subject of numerous studies because of its above-mentioned characteristics and its easy cultivability under controlled conditions. However, there is no evidence in the literature that duckweed has been studied as a source of biostimulating substances. The aims of the present research were to investigate whether duckweed grown under controlled conditions contains potential biostimulating metabolites and exhibits biostimulant activity, using maize as a model crop.

\section{Materials and Methods}

\section{Duckweed Growth Conditions}

Duckweed (Lemna minor L.) was collected from a freshwater basin located near the city of Perugia (Italy). The collected plants were initially disinfected by contact and immersion in a $0.5 \%$ sodium hypochlorite solution. After 1-2 min, they were gently rinsed with distilled water for $1 \mathrm{~min}$. This operation was repeated twice. The plants were transferred to polyethylene trays $(35 \times 28 \times 14 \mathrm{~cm})$ and allowed to grow according to a published procedure (Panfili et al. 2019a). Trays were then positioned into a growth chamber at $23 \pm 1{ }^{\circ} \mathrm{C}$ and light intensity of $100 \mu \mathrm{mol} \mathrm{m}{ }^{-2} \mathrm{~s}^{-1}$ (light/dark photoperiod: $12 / 12 \mathrm{~h}$ ). Plants were maintained under these conditions for eight weeks before the experiments. The culture media were renewed every two weeks with a nutrient solution of the composition described in a previously published article (Panfili et al. 2019a). For maize seed experiments, duckweed was harvested every two weeks before the renewal of the growing medium.

\section{Preparation of the Duckweed Extract and Its Untargeted Phytochemical Characterization}

Ten grams of duckweed was harvested, rinsed thoroughly with water, and dried at $40^{\circ} \mathrm{C}$ for until reaching a constant weight $(72 \mathrm{~h})$. After this, $1 \mathrm{~g}$ DW dried duckweed was ground to a powder using a mortar and pestle and extracted in $100 \mathrm{~mL}$ water (pH 7.0). The resulting suspension was placed on an orbital shaker at $100 \mathrm{rpm}$ for $24 \mathrm{~h}$ in the dark and at $23 \pm 1{ }^{\circ} \mathrm{C}$. After this time, the solid fraction was removed by vacuum filtration on a bucker filter, and the liquid phase was brought to a final volume of $100 \mathrm{~mL}$. This was designated $1.00 \%$ duckweed extract.

The extracts were centrifuged (Eppendorf 5810R, Hamburg, Germany) at $9000 \times g\left(15 \mathrm{~min}\right.$ at $\left.4{ }^{\circ} \mathrm{C}\right)$ and filtered through a $0.22 \mu \mathrm{m}$ regenerated cellulose filter into amber HPLC vials. Phytochemicals were then profiled according to an untargeted metabolomics approach through ultrahigh-pressure liquid chromatography quadrupole-time-offlight mass spectrometry (UHPLC-ESI/QTOF-MS) as previously reported (Rocchetti et al. 2017). Briefly, an Agilent Zorbax eclipse plus column $(50 \mathrm{~mm} \times 2.1 \mathrm{~mm}, 1.8 \mu \mathrm{m})$ with a binary mixture of aqueous acetonitrile $(5-95 \%$ in 34 min linear gradient) was used for chromatographic separation. QTOF-MS acquisition used positive polarity, 
and full scan mode $(100-1200 \mathrm{~m} / \mathrm{z}, 1 \mathrm{~Hz}$, absolute peak height threshold 3000 counts) and the injection volume was $4 \mu \mathrm{L}$. Triplicate sample of the extract were analyzed.

The annotation of raw mass features was done using the software Profinder B.07 (from Agilent Technologies), according to monoisotopic accurate mass (accuracy $<5 \mathrm{ppm}$ ) and the whole isotopic pattern (i.e., isotopic spacing and isotopic ratio) following mass and retention time alignment (Mimmo et al. 2017). Two subsequent annotation steps were carried out, firstly against the database Phenol-Explorer 3.6 (http://phenol-explorer.eu/) for phenolic compounds and then against the database PlantCyc (https://plantcyc.org/) for phytohormones and other plant-related metabolites (Rouphael et al. 2018b). Only the compounds annotated within $100 \%$ of replications, and potentially bioactives were retained and identified.

Phenolic compounds were grouped in sub-classes, and the respective cumulative abundances quantified using calibration curves prepared from pure standard solutions (Extrasynthese, Lyon, France), as reported in previous work (Rocchetti et al. 2019). However, glucosinolates were quantified as gluconapin equivalents (Sigma-Aldrich, Milan, Italy). In both cases, linear fitting calibration (not weighed and not forced to origin) was used.

\section{Maize Growth Conditions and Treatments}

Maize seeds (Zea mays L. cv Belgrano) were sterilized in a solution containing hypochlorite $(0.25 \%)$ for $3 \mathrm{~min}$. Afterward, the seeds were rinsed repeatedly with distilled water. Then, the seeds were left in contact with $10 \mathrm{~mL}$ solution containing $0.00 \%$ (control), $0.01 \%, 0.05 \%, 0.50 \%$, and $1.00 \%$ of duckweed extract (seed priming) for $8 \mathrm{~h}$, found to be the best period for this study (data not shown). Other high dosages $(2.00 \%$ and $8.00 \%)$ were tested in a preliminary screening, but as they negatively impacted maize germination (data not shown), the maximum extract dosage was fixed at $1.00 \%$. After $8 \mathrm{~h}$ of priming, the seeds were placed into covered Petri dishes (10 seeds/plate in triplicate for each treatment) lined with filter paper and moisten with $10 \mathrm{~mL}$ water. These were placed in a growth chamber in the dark at $24 \pm 1{ }^{\circ} \mathrm{C}$. Germination was recorded 4 days after priming, and radicle length was recorded 5 days after priming.

Primed maize seeds were transferred in hydroponic solutions (three replications per treatment and eight plants for each treatment) and grown according to a published procedure (Panfili et al. 2019b). The nutrient solution consisted of $2 \mathrm{mM} \mathrm{Ca}\left(\mathrm{NO}_{3}\right)_{2} \cdot 4 \mathrm{H}_{2} \mathrm{O}, 0.5 \mathrm{mM} \mathrm{MgSO} \cdot \cdot 7 \mathrm{H}_{2} \mathrm{O}$, $0.7 \mathrm{mM} \mathrm{K}_{2} \mathrm{SO}_{4}, 0.1 \mathrm{mM} \mathrm{KCl}, 0.1 \mathrm{mM} \mathrm{KH}_{2} \mathrm{PO}_{4}, 1 \mu \mathrm{M}$ $\mathrm{H}_{3} \mathrm{BO}_{3}, 0.5 \mu \mathrm{M} \mathrm{MnSO}{ }_{4} \cdot \mathrm{H}_{2} \mathrm{O}, 0.5 \mu \mathrm{M} \mathrm{CuSO}_{4}, 0.5 \mu \mathrm{M}$ $\mathrm{ZnSO}_{4} \cdot 7 \mathrm{H}_{2} \mathrm{O}, 0.01 \mu \mathrm{M}\left(\mathrm{NH}_{4}\right)_{6} \mathrm{Mo}_{7} \mathrm{O}_{24} \cdot 4 \mathrm{H}_{2} \mathrm{O}$, and $100 \mu \mathrm{M}$ Fe-EDTA (Panfili et al. 2019b). Samples were maintained at $24 \pm 2{ }^{\circ} \mathrm{C}$ and a light intensity of $150 \mu \mathrm{mol} \mathrm{m}^{-2} \mathrm{~s}^{-1}$ (light/ dark photoperiod: 12/12 h). At the third leaf stage (3 weeks after sowing - 21 days DAS), plants were harvested and submitted to the following analyses.

\section{Duckweed and Maize Nutrient Determination}

The nutrient determinations were carried out in triplicates on duckweed and maize shoot samples, grown as described above, after drying in an oven at $60{ }^{\circ} \mathrm{C}$ until a constant weight had been reached.

Nitrogen quantification was performed on plant samples (1.0 g DW) after digestion with $12.5 \mathrm{~mL} \mathrm{H}_{2} \mathrm{SO}_{4} 96 \%$ (v/v), $7.0 \mathrm{~mL} \mathrm{H}_{2} \mathrm{O}_{2} 30 \%(\mathrm{v} / \mathrm{v})$, and a Kjeldahl tablet. After allowing the digested tissues to cool, $80.0 \mathrm{~mL} \mathrm{NaOH} 32.5 \%$ $(\mathrm{w} / \mathrm{v})$ was added to the samples. Total nitrogen $(\mathrm{N})$ was determined by titration with $\mathrm{H}_{2} \mathrm{SO}_{4} 0.1 \mathrm{~N}$ (Tabatabai and Bremner 1970).

Dried shoots $(0.25 \mathrm{~g} \mathrm{DW})$ were added to $7.0 \mathrm{~mL} \mathrm{HNO}_{3}$ $65 \%(\mathrm{v} / \mathrm{v})$ and $3.0 \mathrm{~mL} \mathrm{H}_{2} \mathrm{O}_{2} 30 \%(\mathrm{v} / \mathrm{v})$ and then digested at $90{ }^{\circ} \mathrm{C}$ for $90 \mathrm{~min}$. The acid digested samples were then filtered, and $\mathrm{P}, \mathrm{K}, \mathrm{Ca}, \mathrm{Mg}, \mathrm{Na}, \mathrm{Fe}, \mathrm{Mn}, \mathrm{Zn}$, and $\mathrm{Cu}$ were quantified by inductive coupling plasma spectrometry (ICP) (Hansen et al. 2013).

\section{Assessments of Biomass Production, SPAD, Leaf Area, and Vigor Index of Maize Seedlings}

At 21 DAS, the shoot and root length and fresh and dry weight were recorded in the maize plants subjected to the different duckweed extract priming treatments. Samples were also subjected to SPAD-value determination (SPAD502 Plus, Konica Minolta, Japan) to estimate the leaf chlorophyll concentration. For this purpose, measurements were taken $5 \mathrm{~cm}$ from the base of the third fully developed leaf, midway between the central vein and the leaf margin. Five leaves were measured and averaged to obtain a single SPAD value for each replicate $(n=3)$.

The area of the third fully developed leaf of the maize plants was estimated from image analysis. A camera was used to acquire the images, which were then processed using ImageJ 1.50i software (Wayne Rasband, National Institute of Health, USA).

The vigor index (VI) was calculated for the treated maize plants where VI was calculated by applying the following equation (Fina et al. 2016):

$\mathrm{VI}=\left(L_{\text {root }}+L_{\text {shoot }}\right) \times G$,

where $L_{\text {root }}$ is the root length and $L_{\text {shoot }}$ is the length of the aerial part of the plants. $G$ is the germination shown by the seeds. 


\section{Statistical Analysis}

Each reported value represents the mean of the data from three independent experiments on at least three biological replicates per experiment. Statistical analysis of the data was performed in an ANOVA manner by analyzing the variance using Duncan's tests at $P<0.05$, using the "emmeans" package in the $\mathrm{R}$ statistical environment (Lenth 2016).

\section{Results}

\section{Duckweed Nutrient Content and Metabolomic Profile of Its Extract}

The aqueous extract was characterized by a high relative abundance of low-molecular-weight phenolics (45\%) and glucosinolates $(31 \%)$ (Table 1). Flavonoids and phenolic acids were present in similar concentrations $\left(1829 \mathrm{mg} \mathrm{kg}^{-1}\right.$ and $1733 \mathrm{mg} \mathrm{kg}^{-1}$ equivalents, respectively). The most abundant flavonoids identified were kaempferol and quercetin and their glucosides, followed by myricetin. Hesperidin was the most abundant flavone, and caffeic acid was the most abundant phenolic acid $\left(812 \mathrm{mg} \mathrm{kg}^{-1}\right)$.
The low-molecular-weight phenolic fraction was characterized by 5-nonadecenylresorcinol, hydroxytyrosol, and 4-hydroxycoumarin. The untargeted metabolomic screening also revealed several glucosinolates, most commonly $n$-(E)$\omega$-(methylsulfanyl)alkanal oxime and $\omega$-(methylsulfanyl)2-oxoalkanoate, followed by indole derivatives. Phytohormones (namely, conjugated auxins, cytokinins, gibberellins, jasmonate-related metabolites, and brassinosteroids) were also detected, but a quantitative assessment would be required to demonstrate that these compounds were present in biologically relevant concentrations. The list of metabolites identified in the duckweed aqueous extract is provided in the supplementary materials, together with individual abundance, retention time, and composite mass spectra data (Online resource ESM_1.xlsx).

\section{Effect of Seed Priming with Duckweed Extract on Maize Germination and Growth}

Seed priming with all concentrations of duckweed extract other than $0.01 \%$ significantly increased maize seed germination and radicle length (Fig. 1a, b). However, this inductive effect was not significantly different between $0.05,0.50$, and $1.00 \%$. Seed priming with $0.05 \%$ and $0.50 \%$ duckweed extract positively and significantly

Table 1 Plant nutrient content in duckweed and phytochemical profile of bioactives (as provided from cumulative abundance per class resulting from untargeted metabolomics) in its aqueous extract

\begin{tabular}{|c|c|c|c|c|c|c|c|c|c|c|}
\hline \multicolumn{11}{|c|}{ Duckweed extract plant nutrients composition } \\
\hline \multirow{2}{*}{$\begin{array}{l}\mathrm{N} \\
\mathrm{mg} \mathrm{g}^{-1} \mathrm{DW}\end{array}$} & \multirow[t]{2}{*}{$\mathrm{P}$} & \multirow[t]{2}{*}{$\mathrm{K}$} & \multirow{2}{*}{\multicolumn{2}{|c|}{$\mathrm{Ca}$}} & \multirow[t]{2}{*}{$\mathrm{Mg}$} & \multirow[t]{2}{*}{$\mathrm{Na}$} & \multirow{2}{*}{\multicolumn{2}{|c|}{$\begin{array}{l}\mathrm{Fe} \\
\mu \mathrm{g} \mathrm{g}^{-1} \mathrm{DW}\end{array}$}} & \multirow[t]{2}{*}{$\mathrm{Zn}$} & \multirow[t]{2}{*}{$\mathrm{Cu}$} \\
\hline & & & & & & & & & & \\
\hline $52.4 \pm 0.6$ & $2.1 \pm 0.3$ & $30.0 \pm 0.9$ & \multicolumn{2}{|c|}{$3.0 \pm 0.2$} & $1.9 \pm 0.4$ & $0.31 \pm 0.2$ & $39.1 \pm 0.1$ & $35.5 \pm 5.2$ & 186.6. \pm 26.4 & $4.3 \pm 0,1$ \\
\hline \multicolumn{11}{|c|}{ Metabolomic profile of the extract } \\
\hline \multicolumn{2}{|c|}{ Other flavonoids $\left(\mathrm{mg} \mathrm{kg}^{-1}\right)$} & \multicolumn{2}{|c|}{ Flavones $\left(\mathrm{mg} \mathrm{kg}^{-1}\right)$} & \multicolumn{3}{|c|}{$\begin{array}{l}\text { Phenolic acids-hydroxycin- } \\
\text { namic acids }\left(\mathrm{mg} \mathrm{kg}^{-1}\right)\end{array}$} & \multicolumn{2}{|c|}{$\begin{array}{l}\text { Low-molecular-weight pheno- } \\
\text { lics }\left(\mathrm{mg} \mathrm{kg}^{-1}\right)\end{array}$} & \multicolumn{2}{|c|}{ Glucosinolates $\left(\mathrm{mg} \mathrm{kg}^{-1}\right)$} \\
\hline \multicolumn{2}{|c|}{$1506.72 \pm 34.26$} & \multicolumn{2}{|c|}{$322.25 \pm 24.68$} & \multicolumn{3}{|c|}{$1732.68 \pm 25.63$} & \multicolumn{2}{|c|}{$6714.99 \pm 405.93$} & \multicolumn{2}{|c|}{$4563.74 \pm 95.04$} \\
\hline
\end{tabular}

Results are presented as mean $\pm \operatorname{SD}(n=3)$

Fig. 1 The effect of seed priming with aqueous duckweed extracts on a maize germination and $\mathbf{b}$ radicle length. Letters, if different, indicate statistically significant differences for $P<0.05$ between treatments $(n=3)$ (a)

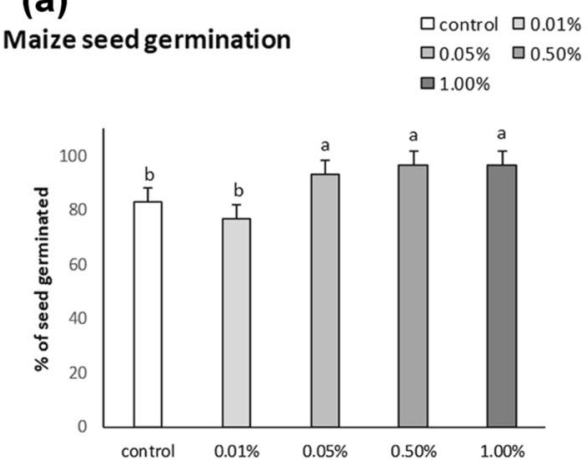

(b) $\begin{array}{ll}\text { Radicle length } & \square \text { control } \\ \square 0.01 \% \\ \square 0.05 \% & \square 0.50 \% \\ & \square 1.00 \%\end{array}$

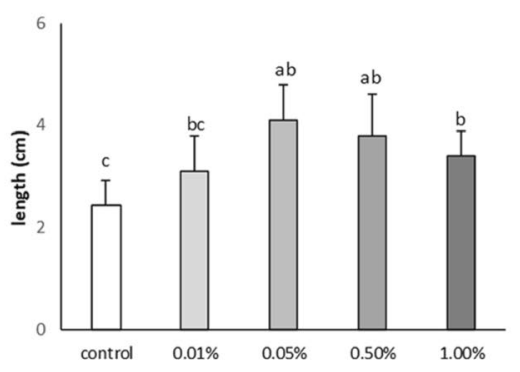


Table 2 Effect of seed priming treatments with duckweed extracts on the shoot and root length and fresh and dry weight of maize at 21 DAS

\begin{tabular}{|c|c|c|}
\hline Seed priming treatment & Shoot length (cm) & Root length $(\mathrm{cm})$ \\
\hline Control & $22.8 \pm 2.4 \mathrm{~b}$ & $13.6 \pm 4.7 \mathrm{~b}$ \\
\hline $0.01 \%$ & $27.0 \pm 6.7 \mathrm{ab}$ & $18.4 \pm 6.7 \mathrm{ab}$ \\
\hline $0.05 \%$ & $31.1 \pm 4.9 \mathrm{a}$ & $18.9 \pm 3.6 \mathrm{ab}$ \\
\hline $0.50 \%$ & $32.5 \pm 4.9 \mathrm{a}$ & $21.5 \pm 1.6 \mathrm{a}$ \\
\hline \multirow[t]{2}{*}{$1.00 \%$} & $29.5 \pm 6.4 \mathrm{ab}$ & $15.0 \pm 1.3 \mathrm{~b}$ \\
\hline & Shoot fresh weight $\left(\mathrm{g} \mathrm{plant}^{-1}\right)$ & $\begin{array}{l}\text { Root fresh } \\
\text { weight ( } g \\
\left.\text { plant }^{-1}\right)\end{array}$ \\
\hline Control & $0.88 \pm 0.17 \mathrm{~b}$ & $0.23 \pm 0.10 \mathrm{c}$ \\
\hline $0.01 \%$ & $1.13 \pm 0.44 a b$ & $0.35 \pm 0.21 \mathrm{bc}$ \\
\hline $0.05 \%$ & $1.21 \pm 0.25 \mathrm{ab}$ & $0.52 \pm 0.13 \mathrm{ab}$ \\
\hline $0.50 \%$ & $1.41 \pm 0.26 \mathrm{a}$ & $0.65 \pm 0.13 \mathrm{a}$ \\
\hline \multirow[t]{2}{*}{$1.00 \%$} & $1.28 \pm 0.3 \mathrm{ab}$ & $0.55 \pm 0.11 \mathrm{ab}$ \\
\hline & Shoot dry weight $\left(\mathrm{mg} \mathrm{plant}^{-1}\right.$ ) & $\begin{array}{l}\text { Root dry weight } \\
\left(\mathrm{mg} \mathrm{plant}^{-1}\right)\end{array}$ \\
\hline Control & $70.8 \pm 3.8 \mathrm{c}$ & $10.2 \pm 2.0 \mathrm{c}$ \\
\hline $0.01 \%$ & $80.7 \pm 7.4 \mathrm{bc}$ & $17.1 \pm 1.5 \mathrm{~b}$ \\
\hline $0.05 \%$ & $86.2 \pm 6.8 b$ & $26.1 \pm 2.1 \mathrm{a}$ \\
\hline $0.50 \%$ & $98.6 \pm 4.1 \mathrm{a}$ & $29.3 \pm 1.7 \mathrm{a}$ \\
\hline $1.00 \%$ & $85.3 \pm 6.4 \mathrm{~b}$ & $25.5 \pm 2.8 \mathrm{a}$ \\
\hline
\end{tabular}

Letters, if different, indicate significant differences for $P<0.05(n=3)$ between treatments

affected shoot length at 21 DAS (Table 2). There was no effect with $0.01 \%$ or $1.00 \%$ extracts. Only priming with $0.50 \%$ duckweed extract had a significant impact on root length (Table 2). The largest impact of duckweed extract on the shoot fresh weight occurred with the $0.50 \%$ extract (Table 2). The root fresh weight was positively and significantly increased when seeds were primed with $0.05 \%, 0.50 \%$, and $1.00 \%$ extract. The shoot dry weight significantly increased when seeds were primed with the three highest concentrations of the duckweed extract, and the largest effect occurred with the $0.50 \%$ treatment (Table 2). Root dry weight was significantly affected by all the concentration of the duckweed extract, with the highest effects when seeds were primed with $0.05 \%$, $0.50 \%$, and $1.00 \%$ extract.

Seed priming with $0.50 \%$ extract significantly increased the vigor index (VI), which was almost doubled in comparison with the control samples (Fig. 2). Concentrations of $0.05 \%$ and $1.00 \%$ also yielded significantly different VI values from those in control samples, while priming with $0.01 \%$ extract had no effect.

Seed priming with $0.50 \%$ extract significantly increased the leaf area of the third leaf (the newly expanded young leaf) at 21 DAS compared with control samples and $0.05 \%$ and $1.00 \%$ extracts also positively

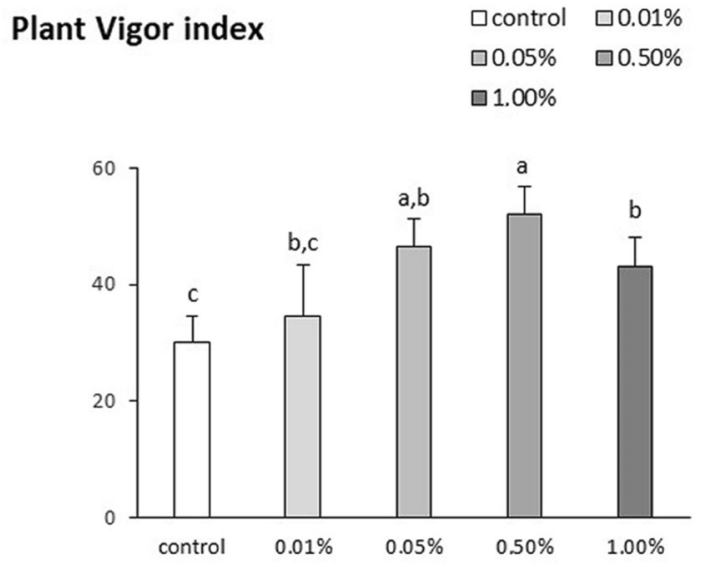

Fig. 2 The effect of seed priming with aqueous duckweed extracts on plant vigor index of maize. Letters, if different, indicate statistically significant differences for $P<0.05$ between treatments $(n=3)$

influenced this parameter, but not significantly (Fig. 3a). Priming with $0.01 \%$ extract had no effect (Fig. 3a). Duckweed extracts at all concentrations significantly increased the concentration of chlorophyll compared with controls (Fig. 3b). 
Fig. 3 The effect of seed priming with aqueous duckweed extracts on $\mathbf{a}$ leaf area and $\mathbf{b}$ chlorophyll content in maize at 21 DAS. Letters, if different, indicate statistically significant differences for $P<0.05$ between treatments $(n=3)$
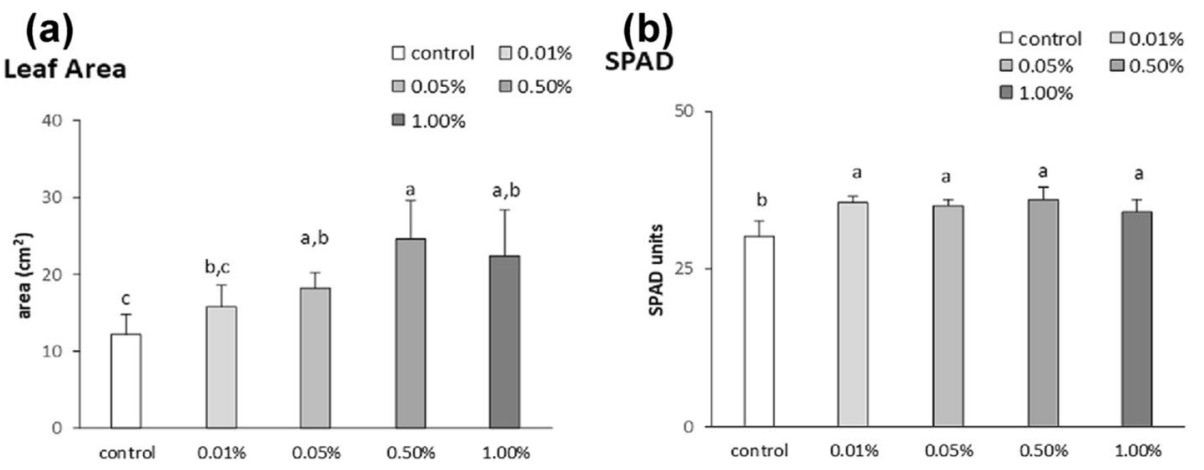

\section{Effect of Seed Priming with Duckweed Extract on Maize Nutrient Content}

Maize samples treated with $0.50 \%$ and $1.00 \%$ duckweed extract had a significantly higher nitrogen content than control samples (Table 3). No significant effects were found with the other concentrations. Maize samples treated with $0.05 \%, 0.50 \%$, and $1.00 \%$ extracts had significantly higher phosphorus, potassium, calcium, and sodium contents compared with the controls, while no significant effects were found with $0.01 \%$ extracts. Treatment with $0.50 \%$ and $1.00 \%$ extracts significantly increased the iron content in maize, and $0.05 \%, 0.50 \%$, and $1.00 \%$ extracts had a significantly positive impact on copper content. No other concentrations affected iron or copper contents. Duckweed extract had no significant impact on the content of manganese or zinc (Table 3).

\section{Discussion}

Given the increasing importance of the use in agriculture of substances with biostimulant activity, this study evaluated the biostimulating potential on maize of an aqueous extract obtained from duckweed grown under controlled conditions. Two classes of bioactive compounds-glucosinolates and phenolics-were detected in the extract from duckweed with untargeted profiling (Table 1). Glucosinolates are specialized secondary metabolites generally associated with Brassica species, which contain a thioglucoside and a sulphonated oxime moiety. They are typically induced after wounding and/or pathogen attack and have also been linked to abiotic stress tolerance, such as response to salinity, UV, and temperature. They may act as signaling molecules and are stored in the vacuole where they can produce bioactive metabolites (isothiocyanates, thiocyanates, oxazolidine-thiones, and nitriles) via myrosinase activity, following tissue damage (Variyar et al. 2014). When exogenously applied, they can affect both the rhizosphere community and plant roots. In vivo, they display several bioactive properties, including bioherbicidal, antioxidant, antimutagenic, and chemoprotective activities (Vig et al. 2009).

Phenolic compounds are a class of plant secondary metabolites displaying a wide array of activities, including growth regulation, interactions with hormones, pigment, and chlorophyll biosynthesis, and have radical scavenging activity (Tuladhar et al. 2021). Polyphenols are involved in plant tolerance to abiotic and biotic stress and play a pivotal role in the mechanisms plants use to adapt to environmental challenges (Naikoo et al. 2019). As with the endogenous pool of polyphenols, exogenously applied phenolics improve tolerance to abiotic stresses such as salinity and oxidative stress (Mei et al. 2020; Parvin et al. 2020).

The phytochemical profile observed in the duckweed extract suggests potential biostimulant activity. However, the absence of previous scientific evidence on the species supporting this effect makes it difficult to determine the actual contribution of the different classes of metabolites found in the extract. Previous reports on this plant, made from biomedical and pharmaceutical perspectives, and using non-targeted screening, described the presence of free amino acids and several phenolic compounds such as anthocyanins, flavones, and other flavonoids, among others (Alkimin et al. 2019; Wahman et al. 2020). Consistent with its secondary metabolites profile, duckweed extracts exhibited antibacterial activity and increased the antioxidant capacity when added to cellulose substrates (González-Renteria et al. 2020; Mohamed et al. 2019).

Seed priming with the aqueous duckweed extract improved seed germination and radicle length in maize (Fig. 1a, b). Such effects are not unusual for plant biostimulants, especially for crops biostimulated with plant extracts (Parađiković et al. 2019). For instance, some commercial biostimulants derived from plant extracts influenced seed germination and the vigor of young seedlings of Lepidium sativum L.. This suggests that plant extracts could act as biological elicitors, depending on their composition (Lisjak et al. 2015). The longer radicles shown by seedlings treated with the duckweed extract indicate an inductive effect on the first phase of the maize seeds development. This effect is in 
line with previous studies on other plant-based biostimulants (Ceccarelli et al 2021).

The impact of the duckweed extract on the development of the maize radicle could also be due to the presence of hormones in the extract (Lucini et al. 2018). Likewise, a plant extract obtained from Giant Reed (Arundo donax L.) had a stimulatory effect on tomato seed germination and development. This was thought to occur because this extract behaved similarly to the hormone gibberellin, perturbing the hormonal balances in treated seeds (Savy et al. 2017). Phytohormones were detected in the duckweed extract, supporting the possibility that the treatment could have modulated the hormone profile in maize plants. Even considering the dilution process during duckweed extraction and the low application rates on maize, phytohormones are potent modulators of plant development processes. However, further experiments are needed to confirm the patterns of maize hormone crosstalk following the duckweed extract application. Exogenous plant hormones are well-recognized plant growth regulators able to modulate plant metabolic processes, and morphological differences in the roots from treated plants can be observed (Huan et al. 2020; Poveda 2020; Slazak et al. 2015).

The duckweed extract affected the length and the fresh and dry weight of the shoot and root of maize seedlings at 21 DAS (Table 2). The effect was dose-dependent, with the $0.50 \%$ concentration having, generally, the most significant impacts on these parameters. The other concentrations displayed different effects, and the loss of efficacy at $0.01 \%$ was probably due to excessive dilution.

There is extensive literature highlighting the effects of biostimulants on the shoot and root development. The increase in plant biomass is generally due to the plant extracts' ability to improve nutrient acquisition (specifically nitrogen) in treated species (Colla et al. 2015; Saavedra et al. 2020). Subsequent increases in nitrogen content can, in turn, elevate pigment content and photosynthetic efficiency. Plants with an improved root system following biostimulant treatments have increased productivity, nutrient uptake, and resistance to stress (Lucini et al. 2018).

Seed priming with duckweed extract also affected the vigor index (VI) of the treated maize (Fig. 2). VI is considered a particularly informative index, as it combines germination data with shoot and root length, allowing a comprehensive estimate of the health status of developing seedlings. For this reason, VI is frequently used to determine whether a plant can achieve normal development or is losing vigor (Fina et al. 2016). The VI data from the present study further underlines the effectiveness of duckweed extract at a concentration of $0.50 \%$ as a plant biostimulant.

The three highest dosages of the duckweed extract caused a general increase in leaf area (Fig. 3a), in line with other studies that have found that biostimulants or vegetal 
plant extracts can significantly stimulate leaf development (Parađiković et al. 2019). In general, plant biostimulants affect leaf area more than the number of leaves per plant (Rouphael et al. 2018a). Since leaf area correlates with plant nutritional status, the increases found in maize following the extract treatments could result from improved nutrient acquisition (Del Buono et al. 2020).

Measurements using SPAD revealed the effect of duckweed extract on chlorophyll content (Fig. 3b). In general, all treatments increased the chlorophyll content. This effect is in line with other studies where species treated with seaweed extracts, and plant protein hydrolysates showed significantly higher SPAD and chlorophyll values than controls (Lucini et al. 2018; Rouphael et al. 2018a). Generally, treatment with the duckweed extract was most effective on maize at a concentration of $0.50 \%$ (see Fig. 4 for the impact of $0.50 \%$ duckweed extract compared with the control).

Since biostimulants can influence the crop ability to assimilate nutrients, the impact of duckweed extract on the nutrient content of maize plants was investigated. The extract concentrations most effective in increasing the nutrient content of the crop were generally the three highest (Table 3). Several explanations have been given to account for the effects of biostimulants on plant nutrition. For example, plant extracts can positively affect the microbial community of soil or induce enzymatic activities (Egamberdieva 2009). It has also been hypothesized that biostimulants may increase nutrient mobility and solubility, as they can stimulate the specific release of certain substances by the root system (Del Buono 2021). Finally, biostimulants can increase root biomass or modify its organization and architecture (Colla et al. 2015). From the results of this study, it can be assumed that the substantial increase in root fresh weight (Table 1) may account for the improved ability of the plants treated with $0.05 \%, 0.50 \%$, and $1.00 \%$ duckweed extract to assimilate nutrients (except

(a)

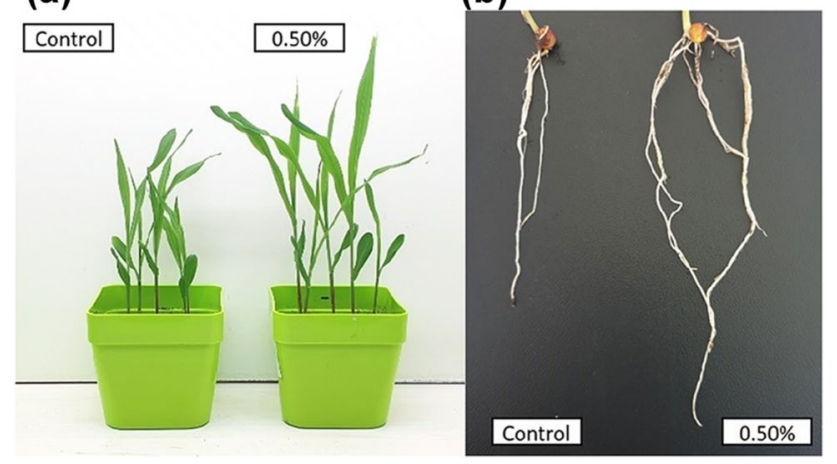

for $\mathrm{Zn}$ and $\mathrm{Mn}$ ). Of particular interest are the significant increases in nitrogen assimilation after the treatment with the duckweed extract (Fig. 3b). This effect may explain the higher chlorophyll values found in treated plants since it is closely related to the content of nitrogen (Rouphael et al. 2018a).

\section{Conclusion}

The present study demonstrated that it is possible to obtain from duckweed, grown under controlled conditions, an extract effective in significantly stimulating physiological and biochemical responses in maize plants. Metabolomic characterization was used to reveal the diversity of specific metabolites that underly the responses found in the crop used in this study. Although plant growth promotion of the duckweed extract was evident, it should be noted that the species was grown under non-natural conditions. Therefore, further studies are needed to reveal whether the duckweed developed under natural conditions may still manifest biostimulatory potential.

Supplementary Information The online version contains supplementary material available at https://doi.org/10.1007/s00344-021-10491-3.

Author contributions Conceptualization: DDB, LL, MT; methodology: DDB, LL, MT; formal analysis and investigation: DDB, MLB, EB, BS; writing - original draft preparation: DDB, MLB, EB, BS, LL, MT; writing - review and editing: DDB, LL, MT.

Funding Open access funding provided by Università Cattolica del Sacro Cuore within the CRUI-CARE Agreement. The authors did not receive support from any organization for the submitted work.

\section{Declarations}

Conflict of interest There is no conflict of interest/competing interest among the authors.

Open Access This article is licensed under a Creative Commons Attribution 4.0 International License, which permits use, sharing, adaptation, distribution and reproduction in any medium or format, as long as you give appropriate credit to the original author(s) and the source, provide a link to the Creative Commons licence, and indicate if changes were made. The images or other third party material in this article are included in the article's Creative Commons licence, unless indicated otherwise in a credit line to the material. If material is not included in the article's Creative Commons licence and your intended use is not permitted by statutory regulation or exceeds the permitted use, you will need to obtain permission directly from the copyright holder. To view a copy of this licence, visit http://creativecommons.org/licenses/by/4.0/.
Fig. 4 The effect of $0.05 \%$ duckweed extract on a shoots and $\mathbf{b}$ roots of maize at 21 DAS 


\section{References}

Abd El-Mageed TA, Semida WM, Rady MM (2017) Moringa leaf extract as biostimulant improves water use efficiency, physiobiochemical attributes of squash plants under deficit irrigation. Agric Water Manag 193:46-54. https://doi.org/10.1016/j.agwat. 2017.08.004

Alkimin GD, Daniel D, Frankenbach S, Serôdio J, Soares AMVM, Barata C, Nunes B (2019) Evaluation of pharmaceutical toxic effects of non-standard endpoints on the macrophyte species Lemna minor and Lemna gibba. Sci Total Environ 657:926-937. https://doi.org/10.1016/j.scitotenv.2018.12.002

Blattner C (2020) Just transition for agriculture? A critical step in tackling climate change. J Agric Food Syst Community Dev 1-6. https://doi.org/10.5304/jafscd.2020.093.006

Ceccarelli AV, Miras-Moreno B, Buffagni V, Senizza B, Pii Y, Cardarelli M, Rouphael Y, Colla G, Lucini L (2021) Foliar application of different vegetal-derived protein hydrolysates distinctively modulates tomato root development and metabolism. Plants 10(2):1-15. https://doi.org/10.3390/plants 10020326

Colla G, Nardi S, Cardarelli M, Ertani A, Lucini L, Canaguier R, Rouphael Y (2015) Protein hydrolysates as biostimulants in horticulture. Sci Hortic 196:28-38. https://doi.org/10.1016/j.scienta. 2015.08.037

Del Buono D (2021) Can biostimulants be used to mitigate the effect of anthropogenic climate change on agriculture? It is time to respond. Sci Total Environ 751:141763. https://doi.org/10.1016/j. scitotenv.2020.141763

Del Buono D, Terzano R, Panfili I, Bartucca ML (2020) Phytoremediation and detoxification of xenobiotics in plants: herbicide-safeners as a tool to improve plant efficiency in the remediation of polluted environments. A Mini-Review Int J Phytoremediation 22(8):789803. https://doi.org/10.1080/15226514.2019.1710817

Del Buono D, Regni L, Del Pino AM, Bartucca ML, Palmerini CA, Proietti P (2021) Effects of megafol on the olive cultivar 'arbequina' grown under severe saline stress in terms of physiological traits, oxidative stress, antioxidant defenses, and cytosolic Ca2+. Front Plant Sci 11:12. https://doi.org/10.3389/fpls.2020.603576

du Jardin P (2015) Plant biostimulants: definition, concept, main categories and regulation. Sci Hortic 196:3-14. https://doi.org/10. 1016/j.scienta.2015.09.021

du Jardin P, Xu L, Geelen D (2020) Agricultural Functions and Action Mechanisms of Plant Biostimulants (PBs). In: The Chemical Biology of Plant Biostimulants. John Wiley \& Sons, Ltd, pp 1-30

Egamberdieva D (2009) Alleviation of salt stress by plant growth regulators and IAA producing bacteria in wheat. Acta Physiol Plant 31(4):861-864. https://doi.org/10.1007/s11738-009-0297-0

Fina BL, Lupo M, Dri N, Lombarte M, Rigalli A (2016) Comparison of fluoride effects on germination and growth of Zea mays, Glycine max and Sorghum vulgare: effects of fluoride on crop plants. J Sci Food Agric 96(11):3679-3687. https://doi.org/10.1002/jsfa.7551

Gebreluel T, He M, Zheng S, Zou S, Woldemicael A, Wang C (2020) Optimization of enzymatic degradation of dealginated kelp waste through response surface methodology. J Appl Phycol 32(1):529_ 537. https://doi.org/10.1007/s10811-019-01894-7

González-Renteria M, del Carmen M-D, Guzmán-García X, Hernández-Calderas I, Ramos-Lopez y MA (2020) Antibacterial activity of Lemna minor extracts against Pseudomonas fluorescens and safety evaluation in a zebrafish model. Saudi J Biol Sci 27(12):3465-3473. https://doi.org/10.1016/j.sjbs.2020.09.043

Hansen TH, De Bang TC, Laursen KH, Pedas P, Husted S, Schjoerring JK (2013) Multielement plant tissue analysis using ICP spectrometry. Methods Mol Biol 953:141. https://doi.org/10.1007/ 978-1-62703-152-3_8
Huan L, Jin-qiang W, Qing L (2020) Photosynthesis product allocation and yield in sweet potato with spraying exogenous hormones under drought stress. J Plant Physiol 253:153265. https://doi.org/ 10.1016/j.jplph.2020.153265

Khan MA, Wani GA, Majid H, Farooq FU, Reshi ZA, Husaini AM, Shah MA (2020) Differential bioaccumulation of select heavy metals from wastewater by Lemna minor. Bull Environ Contam Toxicol 105(5):777-783. https://doi.org/10.1007/ s00128-020-03016-3

Khellaf N, Zerdaoui M (2010) Growth response of the duckweed Lemna gibba L. to copper and nickel phytoaccumulation. Ecotoxicology 19(8):1363-1368. https://doi.org/10.1007/ s10646-010-0522-z

Lasfar S, Monette F, Millette L, Azzouz A (2007) Intrinsic growth rate: a new approach to evaluate the effects of temperature, photoperiod and phosphorus-nitrogen concentrations on duckweed growth under controlled eutrophication. Water Res 41(11):2333-2340. https://doi.org/10.1016/j.watres.2007.01.059

Lenth RV (2016) Least-squares means: the R package lsmeans. J Stat Softw 69:1-33. https://doi.org/10.18637/jss.v069.i01

Lisjak M, Tomić O, Špoljarević M, Teklić T, Stanisavljević A, Balas J (2015) Garden cress germinability and seedling vigour after treatment with plant extracts. Poljoprivreda 21(2):41-46. https://doi.org/10.18047/poljo.21.2.7

Liu Y, Chen X, Wang X, Fang Y, Zhang Y, Huang M, Zhao H (2019) The influence of different plant hormones on biomass and starch accumulation of duckweed: a renewable feedstock for bioethanol production. Renew Energy 138:659-665. https://doi.org/10. 1016/j.renene.2019.01.128

Lucini L, Rouphael Y, Cardarelli M, Bonini P, Baffi C, Colla G (2018) A vegetal biopolymer-based biostimulant promoted root growth in melon while triggering brassinosteroids and stressrelated compounds. Front Plant Sci 9:472. https://doi.org/10. 3389/fpls.2018.00472

Mancosu N, Snyder R, Kyriakakis G, Spano D (2015) Water scarcity and future challenges for food production. Water 7(12):975992. https://doi.org/10.3390/w7030975

Mei Y, Sun H, Du G, Wang X, Lyu D (2020) Exogenous chlorogenic acid alleviates oxidative stress in apple leaves by enhancing antioxidant capacity. Sci Hortic 274:109676. https://doi.org/10. 1016/j.scienta.2020.109676

Mimmo T, Tiziani R, Valentinuzzi F, Lucini L, Nicoletto C, Sambo P, Scampicchio M, Pii Y, Cesco S (2017) Selenium biofortification in fragaria $\times$ ananassa: implications on strawberry fruits quality, content of bioactive health beneficial compounds and metabolomic profile. Front Plant Sci 8:1887. https://doi.org/10. 3389/fpls.2017.01887

Mohamed WA, Mansour MMA, Salem MZM (2019) Lemna gibba and Eichhornia crassipes extracts: clean alternatives for deacidification, antioxidation and fungicidal treatment of historical paper. J Clean Prod 219:846-855. https://doi.org/10.1016/j.jclep ro.2019.02.097

Naikoo MI, Dar MI, Raghib F, Jaleel H, Ahmad B, Raina A, Khan FA, Naushin F (2019) Chapter 9-role and regulation of plants phenolics in abiotic stress tolerance: an overview. In: Khan MIR, Reddy PS, Ferrante A, Khan NA (eds) Plant Signaling Molecules. Woodhead Publishing, pp 157-168

Panfili I, Bartucca ML, Del Buono D (2019a) The treatment of duckweed with a plant biostimulant or a safener improves the plant capacity to clean water polluted by terbuthylazine. Sci Total Environ 646:832-840. https://doi.org/10.1016/j.scitotenv.2018. 07.356

Panfili I, Bartucca ML, Marrollo G, Povero G, Del Buono D (2019b) Application of a plant biostimulant to improve maize (Zea mays) tolerance to metolachlor. J Agric Food Chem 67(44):1216412171. https://doi.org/10.1021/acs.jafc.9b04949 
Parađiković N, Teklić T, Zeljković S, Lisjak M, Špoljarević M (2019) Biostimulants research in some horticultural plant species-a review. Food Energy Secur. https://doi.org/10.1002/fes3.162

Parvin K, Nahar K, Hasanuzzaman M, Bhuyan MHMB, Mohsin SM, Fujita M (2020) Exogenous vanillic acid enhances salt tolerance of tomato: insight into plant antioxidant defense and glyoxalase systems. Plant Physiol Biochem 150:109-120. https://doi.org/10. 1016/j.plaphy.2020.02.030

Poveda J (2020) Use of plant-defense hormones against pathogendiseases of postharvest fresh produce. Physiol Mol Plant Pathol 111:101521. https://doi.org/10.1016/j.pmpp.2020.101521

Puglia D, Pezzolla D, Gigliotti G, Torre L, Bartucca ML, Del Buono D (2021) The opportunity of valorizing agricultural waste, through its conversion into biostimulants, biofertilizers, and biopolymers. Sustainability 13(5):2710. https://doi.org/10.3390/su13052710

Rocchetti G, Lucini L, Chiodelli G, Giuberti G, Gallo A, Masoero F, Trevisan M (2017) Phenolic profile and fermentation patterns of different commercial gluten-free pasta during in vitro large intestine fermentation. Food Res Int 97:78-86. https://doi.org/10. 1016/j.foodres.2017.03.035

Rocchetti G, Lucini L, Rodriguez JML, Barba FJ, Giuberti G (2019) Gluten-free flours from cereals, pseudocereals and legumes: phenolic fingerprints and in vitro antioxidant properties. Food Chem 271:157-164. https://doi.org/10.1016/j.foodchem.2018.07.176

Rouphael Y, Colla G (2020) Editorial: biostimulants in agriculture. Front Plant Sci 11:40. https://doi.org/10.3389/fpls.2020.00040

Rouphael Y, Giordano M, Cardarelli M, Cozzolino E, Mori M, Kyriacou M, Bonini P, Colla G (2018a) Plant- and seaweed-based extracts increase yield but differentially modulate nutritional quality of greenhouse spinach through biostimulant action. Agronomy 8(7):126. https://doi.org/10.3390/agronomy8070126

Rouphael Y, Raimondi G, Lucini L, Carillo P, Kyriacou MC, Colla G, Cirillo V, Pannico A, El-Nakhel C, De Pascale S (2018b) Physiological and metabolic responses triggered by omeprazole improve tomato plant tolerance to $\mathrm{NaCl}$ stress. Front Plant Sci. https://doi. org/10.3389/fpls.2018.00249

Saavedra T, Gama F, Correia PJ, Da Silva JP, Miguel MG, de Varennes A, Pestana M (2020) A novel plant extract as a biostimulant to recover strawberry plants from iron chlorosis. J Plant Nutr 43(13):2054-2066. https://doi.org/10.1080/01904167.2020.17660 79

Sarkar D, Kar SK, Chattopadhyay A, Shikha RA, Tripathi VK, Dubey PK, Abhilash PC (2020) Low input sustainable agriculture: a viable climate-smart option for boosting food production in a warming world. Ecol Indic 115:106412. https://doi.org/10.1016/j.ecoli nd.2020.106412
Savy D, Canellas L, Vinci G, Cozzolino V, Piccolo A (2017) Humiclike water-soluble lignins from giant reed (Arundo donax L.) display hormone-like activity on plant growth. J Plant Growth Regul 36(4):995-1001. https://doi.org/10.1007/s00344-017-9696-4

Sherwood J (2020) The significance of biomass in a circular economy. Bioresour Technol 300:122755. https://doi.org/10.1016/j.biortech. 2020.122755

Slazak B, Jacobsson E, Kuta E, Göransson U (2015) Exogenous plant hormones and cyclotide expression in Viola uliginosa (Violaceae). Phytochemistry 117:527-536. https://doi.org/10.1016/j.phyto chem.2015.07.016

Tabatabai MA, Bremner JM (1970) A simple turbidimetric method of determining total sulfur in plant materials1. Agron J 62(6):805806. https://doi.org/10.2134/agronj1970.000219620062000 $60038 \mathrm{x}$

Tuladhar P, Sasidharan S, Saudagar P (2021) 17-role of phenols and polyphenols in plant defense response to biotic and abiotic stresses. In: Jogaiah S (ed) Biocontrol agents and secondary metabolites. Woodhead Publishing, pp 419-441

Van Oosten MJ, Pepe O, De Pascale S, Silletti S, Maggio A (2017) The role of biostimulants and bioeffectors as alleviators of abiotic stress in crop plants. Chem Biol Technol Agric 4:5. https://doi. org/10.1186/s40538-017-0089-5

Variyar PS, Banerjee A, Akkarakaran JJ, Suprasanna P (2014) Chapter 12-role of glucosinolates in plant stress tolerance. In: Ahmad P, Rasool S (eds) Emerging technologies and management of crop stress tolerance. Academic Press, San Diego, pp 271-291

Vig AP, Rampal G, Thind TS, Arora S (2009) Bio-protective effects of glucosinolates-a review. LWT Food Sci Technol 42(10):15611572. https://doi.org/10.1016/j.lwt.2009.05.023

Wahman R, Graßmann J, Sauvêtre A, Schröder P, Letzel T (2020) Lemna minor studies under various storage periods using extended-polarity extraction and metabolite non-target screening analysis. J Pharm Biomed Anal 188:113362. https://doi.org/10. 1016/j.jpba.2020.113362

Zulfiqar F, Casadesús A, Brockman H, Munné-Bosch S (2019) An overview of plant-based natural biostimulants for sustainable horticulture with a particular focus on moringa leaf extracts. Plant Sci. https://doi.org/10.1016/j.plantsci.2019.110194

Publisher's Note Springer Nature remains neutral with regard to jurisdictional claims in published maps and institutional affiliations. 